\title{
INFORMATION LITERACY AND WOMEN EMPOWERMENT FOR NATIONAL DEVELOPMENT: THE ROLE OF FIRST LADIES IN NIGERIA
}

\author{
Afolabi Mojirayo ${ }^{1}$ and Adeyemo Oladapo ${ }^{2}$ \\ ${ }^{1}$ Centre for Gender and Social Policy Studies, Obafemi Awolowo University, Ile-Ife, Nigeria \\ ${ }^{2}$ Hezekiah Oluwasanmi Library, Obafemi Awolowo University, Ile-Ife, Nigeria
}

Cite this article:

Afolabi M., Adeyemo O. (2021), Information Literacy and Women Empowerment for National Development: The Role of First Ladies in Nigeria. African Journal of Social Sciences and Humanities Research 4(3), 113. DOI: $10.52589 / A J S S H R-$ 0WI6XMSX.

\section{Manuscript History}

Received: 4 May 2021

Accepted: 22 May 2021

Published: 29 May 2021

Copyright $\odot 2020$ The Author(s). This is an Open Access article distributed under the terms of Creative Commons Attribution-NonCommercialNoDerivatives 4.0 International (CC BY-NC-ND 4.0), which permits anyone to share, use reproduce and redistribute in any medium, provided the original author and source are credited
ABSTRACT: Information literacy, the ability to access and utilize essential information empower women's participation in national development and helps them to gain control over their lives. It is key to development and it promotes social inclusion by empowering people to seek and use the information to achieve their goals. It helps women to utilize available resources at their disposal to the best of their ability to achieve optimum results. Women economic empowerment and information literacy cannot be assessed without considering the economic inequality in Nigeria. Women empowerment is the means of reducing women's vulnerability and dependency in all areas of life. Women in Nigeria especially in the rural areas have been neglected, subjected and exposed to poverty with no means of supporting themselves. This paper looks at how information literacy and empowerment can raise the standard of living of women and the role and impact first ladies have played in empowering these women and going forward, how information literacy and women empowerment programmes can be better structured and sustained to further improve their living conditions and the socioeconomic development of the nation.

KEYWORDS: Information Literacy, Empowerment, Development, Gender, Inequality. 


\section{INTRODUCTION}

Information literacy is the ability to locate, evaluate and effectively make use of the needed information. A literate must be able to identify which kind of information is needed, find such information, evaluate and access the information and apply the knowledge acquired to good use. Literacy is the capacity and ability to solve problems or issues using the power of information to build and acquire knowledge. Information literacy is useful for an individual's lifetime, an individual can develop skills that can be helpful for a lifetime by knowing the difference between good and bad information and evaluation of the situation. Literacy is the catalyst that allows women to have input into social and economic decisions that affect their lives. (Davidson, 2017)

Women empowerment is a basic tool for national development. Women are often segregated in society. The empowerment of women further improves the quality and quantity of human resources available to the nation. This shows that if the illiterates can have an opportunity to be empowered, it will improve their lives, develop them as individuals and in turn develop their society and the nation at large. Access to information is empowering. Information is key and access to information brings about knowledge, knowledge on its own is power. Knowledge gained by women displaces ignorance and gives them independence. This allows them to participate in decision making that affects their lives, society and the nation.

There is a need to empower women especially those living in rural areas, to alleviate poverty and raise their standard of living (Okeke, 2018). In recent times, economic growth has become increasingly dependent on the dynamism of small and medium enterprises (Dzafic, 2016). Nigeria has so far encouraged SMEs growth in the nation through loans, grants and so on but there is a need to do more with a special focus on women. There are twice as many women below the poverty line as men. And up to 19 times as many men in executive positions as women.

First Ladies in Nigeria play complementary roles in the administration of their spouses, taking care of very important areas of the lives of the citizenry which are important for the all-round development of the nation. They, therefore, ensure more effectiveness and greater coverage of the welfare of the citizens. The concept of "First Ladies" started in the year 1849 in the United States of America when US President Zachary Taylor called Dolley Madison (wife of US President James Madison who ruled from 1809 to 1817) 'First Lady' at her funeral while paying tribute to her. The concept was subsequently taken up as a title for the wives of presidents and heads of states in many countries of the world.

National development is the process of improving the condition of a nation through economic change and social welfare of the people, for example, quality education, access to clean water, medical care and infrastructural expansion. Development discourse has always been the main focus of governments at national and international levels. The United Nations Organization (UNO), the World Bank, International Monetary Fund, and General Agreement on Tariffs and Trade (GATT) now World Trade Organization are the outcome of the Bretton Woods agreement of 1944. All these organs are geared towards international development. At the level of individual countries, national development is the process of improving the condition of a nation through economic change and the social welfare of the people. It involves critical planning to achieve set goals. This necessitates thinking ahead and initiating pre-determined courses of action. (Datta, 2011). National development is critical and essential to the sustenance 
of the growth of any nation. Heads of States and Presidents of Nigeria, aided by their wives, have contributed immensely to the development and growth of the nation.

The development of a nation is based on both the human capital as well as physical capital of that nation. Ghalli, (1996) said the development has to do with "improvement of human wellbeing, removal of hunger, disease and ignorance, and productive employment for all". The works of first ladies address these issues. Economic growth was seen as a solution to the problem of world poverty in the 1950s and 1960s, but by the 1970s, it was realised that the problems of the poorer nations were not solved. Hence, the concept of development stands not only on the quantitative value of growth but also on the qualitative factors of livelihood, which is the fulfilment of basic human necessities that improve the quality of life of the people as productive agents. (Afolabi 2010)

\section{Importance of Information Literacy}

Information literacy is important for national development because it enables people to create problem-solving approaches and thinking skills to tackle issues by asking questions, finding answers and creating opinions. Information literature is increasingly important in our societies and it is a huge component of literacy policies and strategies and also global policies (UNESCO, 2003). The knowledge acquired by information literacy promotes human development and human capacity building, thereby improving the standard of living, alleviating poverty which in turn provides a basis for effective contribution to the development of the nation. Building information literacy empowers the society to make better persons, equipping the public with necessary skills by developing themselves to be self-sufficient.

Information literacy reduces unemployment in the nation, independent individuals can employ people into the business, thereby reducing unemployment in the nation. An absence of information literacy among women makes room for poverty, forced prostitution, human trafficking, domestic violence, forced abortion and so on. Beyond these, women cannot benefit from the advancement of technology, cannot make decisions on issues that concern them, and cannot make optimal use of healthcare systems, and voting systems.

\section{Women and National Development}

Development is essential and critical to the sustenance and growth of any nation, a nation is regarded as a developed nation when it can provide a good and quality standard of living to the citizens (Lawal, 2011). The joy of any Government is to know the citizens are satisfied with the level of development attained while in office.

To bring about national development through women empowerment and gender equality, there must be effective participation in education, employment and politics. According to Kabeer (2006) for gender equality to take place, women must have the ability to make their own life choices through knowledge acquired from the information. For national development to take place fully, women must be given proper attention. UNESCO (2012) reported that 796 million adults worldwide are not able to read and write and about two-thirds of them (64\%) are women. If these alarming figures can be attended to, there will be a vast improvement in the economic sector, employment opportunities, health sector, agricultural sector and so on. There will also be better participation in the legislative process. All these will bring about development in the nation. 
Women have the power to create, nurture and transform. It is only imperative to invest in them. Investing in women means investing in the people who invest in everyone else. To bring about growth in the nation, women must be given a better platform of opportunities by providing policies that favour women, providing a better business environment by supporting the SMEs and good access to information. Promoting gender equality will result in an economic gamechanger. It would result in higher growth and productivity and greater economic stability. One of the key factors to achieving economic success is to close the gender gap and empower women. It is important to note that lower gender gaps are highly associated with a higher growth rate.

\section{First Ladies in Nigeria}

Historically, the official incorporation of women into development programmes came into UN policy in 1945, and up till now, not all nations of the United Nations have fully incorporated women into development programmes. Participation of First Ladies in their spouses' administration has aided and quickened this incorporation in Nigeria. The efforts of the Heads of States / Presidents have been largely complemented by the programmes and activities of their First Ladies. Although such activities of the First Ladies have been very phenomenal and all-encapsulating, they are largely not well acknowledged, and in most cases undocumented. The need arises, therefore, to focus and critically analyse the activities of the First Ladies and their invaluable contributions to the national development of Nigeria. We examine major highlights, contributions of the activities of the First Ladies of Nigeria from 1985 till date (2020), starting with her Excellency Maryam Babangida who not only pioneered but also popularized the First Ladies syndrome in Nigeria. The First Ladies in the period of our review include:

\begin{tabular}{|l|l|l|l|}
\hline Name & Term Begins & Term Ends & President or Head of State \\
\hline Maryam Babangida & 27 August 1985 & 26 August 1993 & Ibrahim Babangida \\
\hline Margaret Shonekan & 26 August 1993 & 17 November 1993 & Ernest Shonekan \\
\hline Maryam Abacha & 17 November 1993 & 8 June 1998 & Sani Abacha \\
\hline Fati LamiAbubakar & 8 June 1998 & 29 May 1999 & AbdulsalamiAbubakar \\
\hline Stella Obasanjo & 29 May 1999 & 23 October 2005 & Olusegun Obasanjo \\
\hline Turai Yar'Adua & 29 May 2007 & 9 February 2010 & Umaru Musa Yar'Adua \\
\hline Patience Jonathan & 9 February 2010 & 6 May 2010 & Goodluck Jonathan (Acting) \\
\hline Patience Jonathan & 6 May 2010 & 29 May 2015 & Goodluck Jonathan \\
\hline Aisha Buhari & 29 May 2015 & Till date & Muhammadu Bahari \\
\hline
\end{tabular}

The level of development of a nation can only get better through innovative projects and good government policies.

The first ladies have utilized their offices and pet projects as gender-mainstreaming platforms engaging in gender gap-closing programmes and bringing women marginalization and illiteracy in Nigeria to the forefront (Ajayi, 2010) Most of the programmes were not only to bring about changes to their lives alone but to make them major contributors to the development of the nation. 
This discourse on the pet projects of these First Ladies and the socio-economic impacts they created in the nation reveals the important roles of women in development. Apart from their pet projects, these First Ladies served as guardians of their family home fronts. They created emotional and psychological balance in their men as the latter ruled the nation. They served as great motivators, ingraining virtues in the female gender, in a largely patriarchal society like Nigeria.

The need arises therefore to focus and critically analyse the activities of the First Ladies and their invaluable contributions to the national development of Nigeria.

\section{Information Literacy and Gender Inequality}

We live in an information society with a large volume of information governing our everyday life and activities. Unfortunately, some women do not have access to this information. According to Georgiadou (2015), to fully participate in the economic and developmental society, information must be harnessed. The economic, social, cultural and all other human activities are dependent on information and knowledge. As a result of the knowledge-based society we live in, companies, enterprises and also the political terrain tend to attract literate individuals who they feel are competent in such specific sectors. There is a gender gap in information dissemination in society, it is, therefore, compulsory to promote gender equality by encouraging girl-child education, gender-sensitive policies to reduce the gender gaps and empowering women to contribute to the development of the nation. There have been many commitments both internationally and nationally towards gender equality, education and literacy. Examples include the 1979 Convention on the Elimination of all Forms of Discrimination Against Women (CEDAW) which affirmed literacy as competent in addressing gender inequality. Another example is the fourth world conference on women, Beijing declaration and platform for action which addressed the issue of women's right to education. It also includes Education For All (EFA) which addresses ways to improve levels of women literacy and achievement of gender equality. UNESCO initiative for empowerment also focuses on ways to empower women and girls.

With all these campaigns and commitments, the UNESCO initiative for empowerment report shows that only 6 out of the 32 countries in the initiative recorded a net decrease in the number of non-literate women (UIL, 2012)

\section{The Need for Women Empowerment ProgrammeS}

To achieve a literate society, projects must be embarked upon by firstly raising awareness then teaching individuals and groups the basic way to find, evaluate, organise, use and communicate information. This enables individuals to make proper decisions and solve problems. Individuals and groups in the society through projects can empower women with skills for their development. Skills acquisition is an avenue for women to have a better standard of living, pay for standard education and be better placed in society.

It is highly important to make available empowerment programmes for women. Women are sidelined in the nation, as a result of this, the girl child is often excluded from going to school and getting educated, this leads to a greater percentage of women who are illiterates. According to World Literacy Foundation, two-thirds of the world illiterate adults are women, as a result of the alarming rate of illiteracy in the nation, it is imperative to make available empowerment programmes for these women to raise their standard of living and allow them to contribute 
economically, socially and politically in the nation.

Empowerment programmes can be done by the government, private sectors and other bodies like the NGOs. Empowerment programmes can be the provision of standard education, training like tailoring, weaving and provision of equipment to startup businesses and enterprises. Funds can also be provided like grants and loans to start-up Small Medium Enterprises (SMEs). These empowerment programmes give women opportunities to cater for themselves and their families and even employ other individuals, thereby alleviating poverty in the society, improving the employment rate, reducing crime rate and developing the economy of the nation.

Closing the gender gap through information literacy and empowerment of women can be done using different types of initiatives backed up by an intensive and efficient style of awareness to make initiatives and ideas effectively. For instance, the national framework on girls and women's education set up in Nigeria was designed to cater for women by taking them through skill acquisition programmes. This gives such women opportunities to be entrepreneurs. In Indonesia for instance, a mother's newspaper was set up to encourage women to learn how to read and write and even contribute to the newspaper, thereby improving their writing skills. Such innovative programmes go a long way in improving the lives of women which reduces dependency in society and the nation. Other innovative programmes include Women Empowerment Oriented Life Skills Learning which focuses on empowering women to make use of local resources to generate income for themselves. Also in Turkey, there is a father's support programme where men are encouraged to support their women in the home and encourage them to be better equipped for their benefit and society. In Nigeria, the government initiated the women's fund for economic empowerment and business development for women entrepreneurs. Also, the 'second chance' initiative is to re-introduce dropped out women as a result of pregnancy back to school. New and more innovative policies should be put in place to support women in Nigeria. An example of this is the National Policy on Sexual Harassment in educational institutions, this will address the discouragement women encounter in tertiary institutions.

In 2013, INTELS Nig. Ltd launched women empowerment and system synergy intending to empower women in rural areas by teaching them tailoring and fashion designing. Others include She Leads Africa aimed at helping women develop their own ideas, UNIC foundation, African Women Power and WIMBIZ. All these innovative empowerment programmes are available for women to be independent and better placed in society. With the women poverty rate still on the high side, it is obvious the nation still needs more of such innovative programmes to further aid women development.

\section{Nigerian First Ladies and Their Developmental Roles}

\section{Maryam Babangida}

Late Dr. (Mrs.) Maryam Babangida was the first lady of Nigeria between 1985 and 1993. She was the first to use the title of the first lady and also popularized the first lady concept in Nigeria. She became the First Lady in 1985 and 1987, she started the Better Life For Rural Women programme. Her development programme touched several lives, improving the standard of living of women in the rural areas; she was known for her philanthropic activities. She engaged in advocacy to create a better standard of living for the people. She believed women were neglected and relegated in society so she went all out in giving women and the 
entire population a better life and better living conditions by improving the literacy level of citizens. She launched schools, clinics, women training centres, and child daycare centres. When founded the better life programme for rural women in 1987, the initiative benefitted women in tremendous ways by generating a source of income for them, thereby improving their quality of life as individuals than society and in the long run, result in the national development of the country. She went further in establishing a research training centre known as 'The Maryam Babangida National Centre for Women's Development' in 1993. This centre propelled women towards self-actualization, self-emancipation and personal fulfilment. She was also a team player which she exhibited by forming a team of highly capable and goaldriven women called 'The Maryam Babangida Think Tank'. She alongside her team ensured that women affairs became a national issue which led to the establishment of the National Commission for Women Affairs which later became the Ministry of Women Affairs.

Maryam Babangida launched several welfare programmes, for instance, she launched cooperatives, shops, market centres, cottage and small industries. She empowered women in some vocational training like soap making, weaving, dressmaking and baking. She encouraged women to be information literate by providing rural and adult education for them.

The health and wellbeing of women are paramount in propelling them in developing themselves in achieving set goals and contributing to the nation's development. Maryam, fully aware of this, provided women with maternity clinics and health centres. She made available awareness and sensitization programmes on simple hygiene, family planning and the importance of child care, she also collaborated with UNICEF to fight the six deadly diseases (polio, diphtheria, whooping cough, diarrhoea, cholera and measles). She also emancipated women empowerment and collective action (bringing women together and closer for better understanding and resolution of their problems) and women participation in leadership roles.

Maryam raised the social consciousness of women by informing them about their rights, as well as their social, political and economic responsibilities. She also enlightened and educated women on opportunities available to them in their communities. The Better Life for Rural Women programme achieved a lot with the establishment of 9,492 cooperatives societies for women to have access to finance and sundry resources, 1435 cottage industries, 784 farms and gardens, 495 shops and markets, 1095 multipurpose women centres for skill acquisition and 135 fish and livestock farms.

\section{Margareth Shonekan}

Margareth Shonekan was the first lady from the period of August to November 1993. She worked in the Federal service of Nigeria and rose to become the Head of Service in the nation. She was meritorious, hardworking and conscientious. During this period, she was a source of encouragement to women who aspired to reach leadership positions and those that wanted a better life and independence for themselves.

\section{Maryam Abacha}

Maryam Abacha served as the first lady between 1993 and 1998. She founded the Family Support programme (FSP). She was concerned with improving the families in Nigeria. She advocated for putting smiles on the faces of children, giving parents the ability to take care of their children and putting families on a better standard of living. The programme was expected to bring love and unity to families, reducing divorce and family problems. The Family Support 
programme had projects that covered areas like health, agriculture, food and nutrition and education.

In the area of health, she provided immunization programmes, maternity child care and community based primary health care. She made available treatments for those suffering from child abuse, abortion, AIDS and other sexually transmitted diseases and mental illness.

Concerning food and nutrition, she created a nutrition policy and eradication of Iodine Deficiency Disorder. In education, community-based guidance and counselling were established. She also established literacy and vocational centres. She believed that empowering parents through literacy programmes provides economic balance to cater for their entire family. In agriculture, through her FSP initiative, she provided agro-processing and packaging industries, livestock production, fish production and vegetable production.

\section{Fati Lami Abubakar}

Retired Justice Fati Abubakar served as the first lady between 1998 and 1999. She served as a high court judge and founded the Women Rights Advancement and Protection Alternative. (WRAPA). This non-governmental organization provided her with an opportunity to advocate, articulate and propagate women, relating to the advancement and protection of their rights. This initiative was concerned with the rights of women, women empowerment and self-reliance and elimination of violence against women. She was also an advocate of women being literate enough to reach the peak of their careers, she touched the lives of women, educating them and giving them a voice for the achievement of equality. She organised free counselling services for women and social counselling for families. She organised training programmes for women empowerment and adult literacy programmes and civic education for women.

\section{Stella Obasanjo}

Stella Obasanjo was the first lady of Nigeria between 1999 and 2005. Stella Obasanjo established a pet project named Child Care Trust (CCT). The trust is a non-profit NGO founded on 9th May 2000. CCT catered for citizens who are physically challenged with a motto 'sowing the seeds of hope', the project goal is to put smiles on the faces of women and the entire populace that are physically challenged giving them reasons to live and enjoy life, raising their hope for the future and empowering and equipping them with vocational jobs, raising their literacy level with the educative platform and better health.

In the area of information services and management, she provided data banks which served as an information resource for handicaps and providing materials for social researchers, conducting research on all areas of disability, its prevention and management, serving as a networking centre and clearinghouse for information on early childhood issues, policies, programmes and organisation.

The project also took care of social and child welfare, providing medical, social and mental development services for all children especially the handicapped.

\section{Turai Yar' Adua}

Turai Yar' Adua was the first lady of Nigeria between 2007 and 2010. She launched her project, Women and Youth Empowerment Foundation (WAYEF) in 2008. The project targeted women 
and youths by giving them a better quality of life. She believed every Nigerian should have access to health care and the devastating rate of the rise of cancerous diseases gave her the challenge of developing an international cancer centre in Abuja. She also organised entrepreneurship programmes and vocational training programmes. Her project also catered for women in the area of maternal and newborn health improvement programmes, screening programme for breast and cervical cancer, HIV/AIDS and STDs intervention programme and diabetes awareness and educative programmes.

WAYEF also embarked on interventions in the area of poverty reduction, drug abuse and lifelong education to achieve a literate society. She rehabilitated health centres, provided empowerment programmes with tools and machines to equip them and also equipped prison workshops with working tools to make inmates skilful and self-reliant after serving their jail terms.

\section{Dame Patience Jonathan}

Dame Patience Jonathan served as the first lady of Nigeria between 2010 and 2015. Dame patience Jonathan initiated her project called the Women for Change Initiative (WCI). She used this project to raise awareness for the improved welfare of women believing that women should be given opportunities for a better quality of life. She championed the $35 \%$ affirmative action for women to be included in the decision-making process in the country. She believed all women should be literate and empowered. She also sponsored treatment and surgery of children and some adults with heart conditions and joined the global fight against HIV/AIDS.

\section{Aisha Buhari}

Aisha Buhari is the present First lady of Nigeria. Aisha is a women's right activist and child right advocate and she has criticised child marriage and homosexuality. Aisha Buhari is a vocal advocate of women's rights and children rights, she is also an advocate of child education which propels a child to have a better quality of life in future. She is also an advocate of sex trafficking and sexual abuse. Aisha Buhari initiated her project called future Assured which was founded to continue her advocacy work for the health and wellbeing of women and children through community mobilisation and health promotion, giving them better and quality health care. Through the project, Aisha has been working with the Internally Displaced Persons (IDP) providing relief materials and empowering them. She has also been encouraging young people to embrace agriculture.

A cursory examination of the projects, activities and initiatives of Nigerian's First ladies reveals that their contributions are

- $\quad$ potential drivers for Millennium Development Goals (MDGs)

- $\quad$ potential drivers for sustainable Development Goals (SDGs)

- geared towards the realisation of gender equality and equity in various dimensions and

- $\quad$ geared towards the realisation of a literate society 
African Journal of Social Sciences and Humanities Research

ISSN: 2689-5129

Volume 4, Issue 3, 2021 (pp. 1-13)

www.abjournals.org

The activities of the first ladies

- encouraging economic participation

- $\quad$ ensured health and well-being of women

- encouraged literacy and educational attainment, socio-economic and political empowerment.

- $\quad$ encouraging women independence and self-reliance

The activities of the first ladies are in alliance with international treaties and United Nations Convention such as

- $\quad 1951$ ILO Convention on equal remuneration

- $\quad 1952$ Convention on the political rights of women

- $\quad 1960$ UNESCO Convention against discrimination in Education

- 1979 UN Convention on the Elimination of all Forms of Discrimination Against Women

- $\quad 1993$ UN Declaration on the elimination of violence against women

\section{Challenges of Information Literacy and Women Empowerment programmeS}

Implementing initiatives and actualizing innovative ideas meet stumbling blocks along the way. That is why some programmes do not last long, some do not even materialise, while others are not so effective. Some of these challenges include

- Poor awareness programmes: A lot of empowerment programmes and initiatives go unnoticed because of poor awareness and publicity. Women living in rural areas are mostly affected by these. They do not have access to media facilities or media devices like television, radio, internet and so on.

- $\quad$ Traditional belief system: Some women believe and accept that they are not supposed to be empowered and independent, but just to take care of the home, bear and raise children.

- Lack of literacy materials: There are inadequate literacy materials for learning which creates a huge problem in teaching women and the entire populace.

- Inadequate sustainable public libraries and information centres: There are insufficient public libraries and information centres in Nigeria especially at the grassroots level and the few available are not well equipped with relevant and up to date information/resource materials to cater for members of the society especially women.

- $\quad$ Lack of continuity: Projects embarked upon by first ladies are usually stopped by the incoming first lady who would want to introduce her own pet project, ideas and innovation.

- Lack of relevant data and non-availability of current and correct information: To achieve good developmental goals, there has to be relevant data to feed the plans laid down. 


\section{RECOMMENDATIONS}

Awareness programmes must be thoroughly executed with proper publicity in remote areas using mediums that will favour them. Also, the perception and orientation of some women need to be addressed by revealing to them that the responsibilities of women are more than just taking care of the home front but also to be literate, empowered and independent. Government, private bodies and NGOs can provide literacy materials and equip information centres

The incoming administration should make it a responsibility to support the various projects of the former first lady, for the continuity and sustainability of such projects, merging them with the new projects and thereby achieving even better developmental goals. Alternatively, the programmes can be integrated into the specific ministry or government agency statutorily saddled with that responsibility.

For correct and up to date information, the Federal Office of Statistics must be fully equipped to provide relevant and timely information. Citizens must also be ready to divulge and reveal information without any manipulation whatsoever.

\section{CONCLUSIONS}

The position of the first lady has gone beyond ceremonial, to be a more functional office. The developments recorded in the nation have been influenced by the first ladies' pet projects. The qualities of the first ladies and their activities are part of the history of national development and should not be ignored.

The programmes of the first ladies directly addressed the vulnerable ones in the society, helping them in alleviating their plight through their literacy and empowerment programmes. Their inputs to the cause of women and children have yielded positively in terms of women's welfare and their economic contribution to development.

The programmes and initiatives for women empowerment are the major and permanent solution towards poverty alleviation in the country. The sharing or distribution of money or food items will only solve temporary needs. Bringing up innovative ideas and empowerment programmes will make women independent and resourceful for themselves and the nation at large.

\section{REFERENCES}

Afolabi, M.M. (2010). Poverty Alleviation and National Development in Nigeria Through Women Empowerment. International Association For Feminist Economics. Universidad Nacional de General Sarmiento, Buenos Aires, Argentina. Online https://editorialexpress.com/cgi-bin/conference/download.cgi? db_name=IAFFE2010\&paper_id $=166$

Ajayi K. (2010) The concept of first lady and politics in Nigeria. Council for the Development of Social Science Research in Africa, pp13.

Datta, A.K (2010) Integrated material management: A functional approach. New Delhi: Prentice-Hall International Publishers. 
Davidson C. (2017) Information is for everyone. Why literacy is a gender equality issue. World Association of Newspapers and News Publishers, 4th Aug 2017.

Dzafic Z. Babagic A (2016) The role of the government in Entrepreneurship Development: Evidence from Bosnia and Herzegovina. Journal of Economics and Business. Vol 14: 1. 68-79.

Georgiadou E (2015) Information literacy and gender inequality. Western Balkan information literacy conference, BIHAC. June 17-20th Bihac, Bosnia and Herzegovinia, P59-70.

Ghalli, B (1996) Agenda for Democratization (supplement to reports A/50/332 and A/51/512 on democratization (UN Publications)

Kabeer N. (2006) Gender equality and women's empowerment: A critical analysis of the 3rdmillennium development goal, gender and development, 13:1, 13-24

Lawal T \& Oluwatoyin A (2011) National development in Nigeria: issues, challenges and prospects. Journal of public administration and policy research vol 3 (9) pp.237-241.

Okeke C (2018) Women Empowerment and Development in Nigeria. Nwafor Orizu Journal of Educational Research and Development. 319- 324.

UIL (2012) The global life mid-term evaluation report 2006-2011: looking forward with literacy initiative for empowerment (LIFE) UNESCO

UNESCO (2003) Towards an information literate society. Found at $\mathrm{http}: / /$ therightinformation.org Challenges facing women empowerment in contemporary Nigeria. Browse the library. Challenges facing women empowerment in contemporary Nigeria / Gender Hub, www.genderhub.org/get-in-the-know/resourcelibrary/challenges-facing-women-empowerment-in-contemporary-nigeria/

UNESCO Institute for Statistics (2012) Adult and Youth Literacy: Global Trends In Gender Parity Microsoft Word - Fact_Sheet_2010_Lit_editv5.doc (unesco.org) 